\title{
SPATIAL DISTRIBUTION AND POTENTIAL OF METROXYLON SAGU ROTTB. FOREST IN SOUTH KALIMANTAN, INDONESIA
}

\author{
Kissinger*, Pitri, Rina Muhayah N. \\ Faculty of Forestry, University of Lambung Mangkurat Banjarbaru, \\ South Kalimantan, Indonesia \\ *E-mail: durror2ali@gmail.com
}

\begin{abstract}
Metroxylon sagu Rottb is a plant species of wetland that can produce carbohydrates. South Kalimantan is the $4^{\text {th }}$ largest sago producer in Indonesia. Banjar district is one of the areas where covered by M.sagu forest. This study aims to analyze the spatial distribution and potential of M.sagu forest in Banjar district, South Kalimantan. The method of data collection was done by square plot. The $20 \mathrm{~m} \times 20 \mathrm{~m}$ plots consist of at least 3 locations as samples of M.sagu forest. The $20 \times 20 \mathrm{~m}$ quadrats were used to record trees with diameter $=20 \mathrm{~cm}$. The vegetation parameters measured were number of individuals, diameter and height. Spatial data was collected from secondary data. Spatial distribution of M.sagu forest analyzed by using ArcGIS software. The potential of sago forest is analyzed by calculating the diameter, height and volume of trees. The area covered by M.sagu forest in Banjar Regency is 401.62 ha. There are 2 subdistricts that have the largest M.sagu forest in Banjar district, namely Sungai Tabuk sub district and Astambul sub district. M.sagu forest area is $0.09 \%$ of the total area of Banjar district. The potential of M.sagu forest with a diameter $>20 \mathrm{~cm}$ is 119 trees/ha. The number of individual mature trees of M.sagu (diameter $>50 \mathrm{~cm}$ ) reaches 48 stems/ha. The total potential production of wet starch from M.sagu forest in Banjar district is 3,855 tons. Banjar district is an area that has potential high M.sagu starch production in South Kalimantan.
\end{abstract}

\section{KEY WORDS}

Metroxylon sagu, spatial distribution, potential, Banjar district, wetland.

Wetland ecosystems contribute to (i) providing food, water, fiber, bioenergy, biochemical, and genetic resources, (ii) regulating hydrology, climate, erosion and pollination, (iii) supporting the development process of soil and nutrient formations, (iv) socio-cultural development (FAO. 2008). Inland wetland is a form of wetland ecosystem that has an important role in maintaining environmental balance.

The role of inland wetlands as food providers can be obtained from various species of plants and animals. An important form of food that can be provided by the inland wetland ecosystem is as a source of carbohydrates. Metroxylon saguRottb is known as an inland species plant of wetland that can grow naturally or be cultivated. M.sagu is a plant species that can produce carbohydrates.

The carbohydrate content of M.sagu starch is higher than rice (Bintoro. 2008). Starch from M.sagu can also be grouped as functional food (Alfonfs and Rivaie. 2011). M.sagu proved beneficial for health. The glycemic index is in the good category (Buykenet al. 2006). M.sagu can also be used as raw material for bioenergy (Syakir and Elna. 2013). M.sagu is easy to grow without complicated maintenance, its cultivation does not change the pattern of hydrological system in wetlands.

The Indonesian government's food development policy prioritizes sago as one of the leading cultivated foods. According to Presidential Regulation Number 18 of 2020 concerning the 2020-2024 RPJMN, Sago is included in 5 important plant commodities (coffee, cocoa, rubber, coconut and sago) for the development of the food industries.

M.sagu can be found in the tropics in Southeast Asia and the Oceania region (Bintoroet al. 2014). According to Nurlestari (2000), the area of M.sagu forest in Indonesia is around 
$1,111,280$ ha. M.sagu productivity per hectare per year can reach 18 tons of wet starch of sago, so that the potential for M.sagu starch production in Indonesia is 20 million tons/ year.

South Kalimantan is one of place that producing starch of M.sagu. South Kalimantan is the $4^{\text {th }}$ largest sago producer in Indonesia after Riau, Maluku and Papua. The area of M.sagu forestin South Kalimantan Province is relatively wide reaching 7,857 hectares with production was 4,511 tons in 2017. M.sagu is widely available in Banjar, Tapin, and Barito Kuala Regencies (Wahyuningtyaset al. 2018). According to the field observation, the others area in South Kalimantan covered by M.sagu forest are Hulu Sungai Utara district, Hulu Sungai Selatan district and Hulu Sungai Tengah district. Sago starch production tends to decline to 3,724 tons in 2021 (Indonesia Ministry of Agriculture. 2020)

M.sagu is an important commodity because the area of South Kalimantan has many wetland areas that allow sago to grow well. Banjar Regency is known to have the largest M.sagu area in South Kalimantan, but the distribution of M.sagu forest have not been accurately identified and documented. This study aims to analyze the spatial distribution and potential of M.sagu forest in Banjar district, South Kalimantan. This research is important as an effort to develop M.sagu forest as a potential food source for the community.

\section{METHODS OF RESEARCH}

The research was conducted in the Banjar district, South Kalimantan, Indonesia. Geographically, it is located at the coordinates between $2^{\circ} 49^{\prime} 55^{\prime \prime}-3^{\circ} 43^{\prime} 38^{\prime \prime}$ South Latitude and $114^{\circ} 30^{\prime} 20^{\prime \prime}-11^{\circ} 533^{\prime} 37^{\prime \prime}$ East Longitude. The research object used is the M.sagu forest area located in the Banjar Regency, South Kalimantan. Description of the M.sagu forest in Banjar district is shown in the figure 2. The research tools used are:

- A set of terrestrial survey equipment (phi band for measuring diameter, laser meter for measuring height, GPS, tally sheet, camera for documentation);

- A set of data processing equipment (a set of computers, printers, thematic layers, Arc GIS software for geospatial data processing and Microsoft Excel software for data analysis).

The data collection procedure carried out is as follows:

- M.sagu forest vegetation. Determination of the plot sampling to measuredt vegetation parameter of M.sagu was carried out by purposive sampling. The method of data collection was done by square plot. The $20 \mathrm{~m} \times 20 \mathrm{~m}$ plots consist of at least 3 locations as samples of M.sagu forest. The $20 \times 20 \mathrm{~m}$ quadrats were used to record trees with $\mathrm{DBH}$ (Diameter at Breast Height) $20 \mathrm{~cm}$. The vegetation parameters measured were number of individuals, diameter and height;

- Geospatial data collection. Spatial data was collected from secondary data such as the Geospatial Information Agency, the Forestry Service, Geospatial Information Laboratory, Faculty of Forestry, ULM and reference review. Data collection was carried out including composite image data from Google Earth services, area function maps, administrative maps and road network maps and river maps.

Spatial distribution of M.sagu forest consist of:

- Composite image processing. Image interpretation was done visually (on screen digitization) of the composite image to classify land cover of M.sagu forest and non M.sagu forest. Classification was carried out based on differences shown by elements of image interpretation such as color (tone), shape, pattern, texture, and association. The classification of vegetation cover obtained is M.sagu forest area and non M.sagu forest area. Image processing was done by using Arc Gis software;

- Percentage of interpretation accuracy. Sample points were spread over several areas which were interpreted based on composite image analysis as M.sagu forest and nonM.sagu forest. The method of determining the sample point for interpretation testing was done purposively. There were 50 sample points for testing the interpretation results of the classification of sago forest and non-sago forest. Percentage of interpretation accuracy was calculated by using following formula:

Percentage of accuracy $=$ (interpretation value/observed value) $\times 100 \%$ 


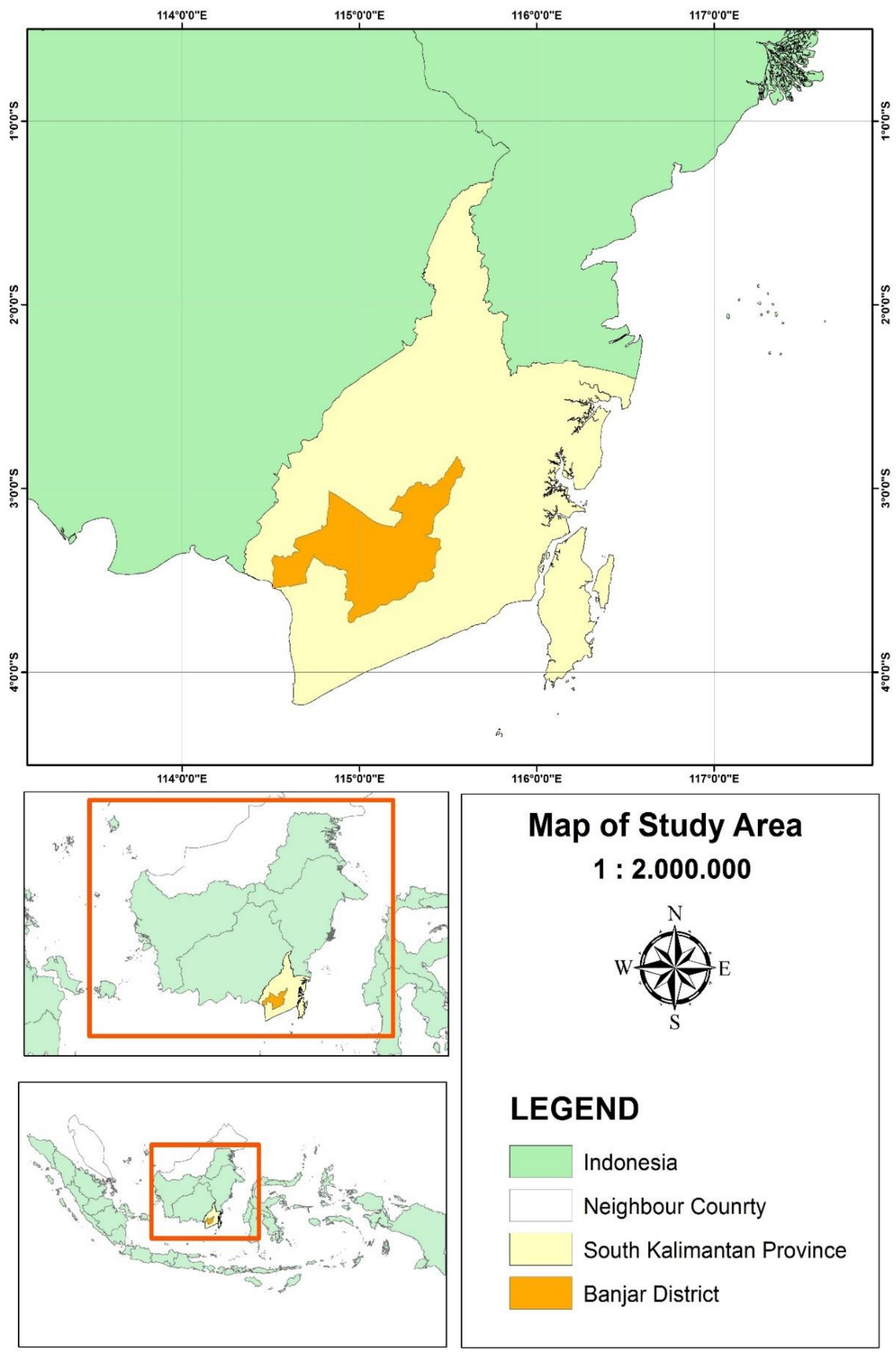

Figure 1 - The location of research area 

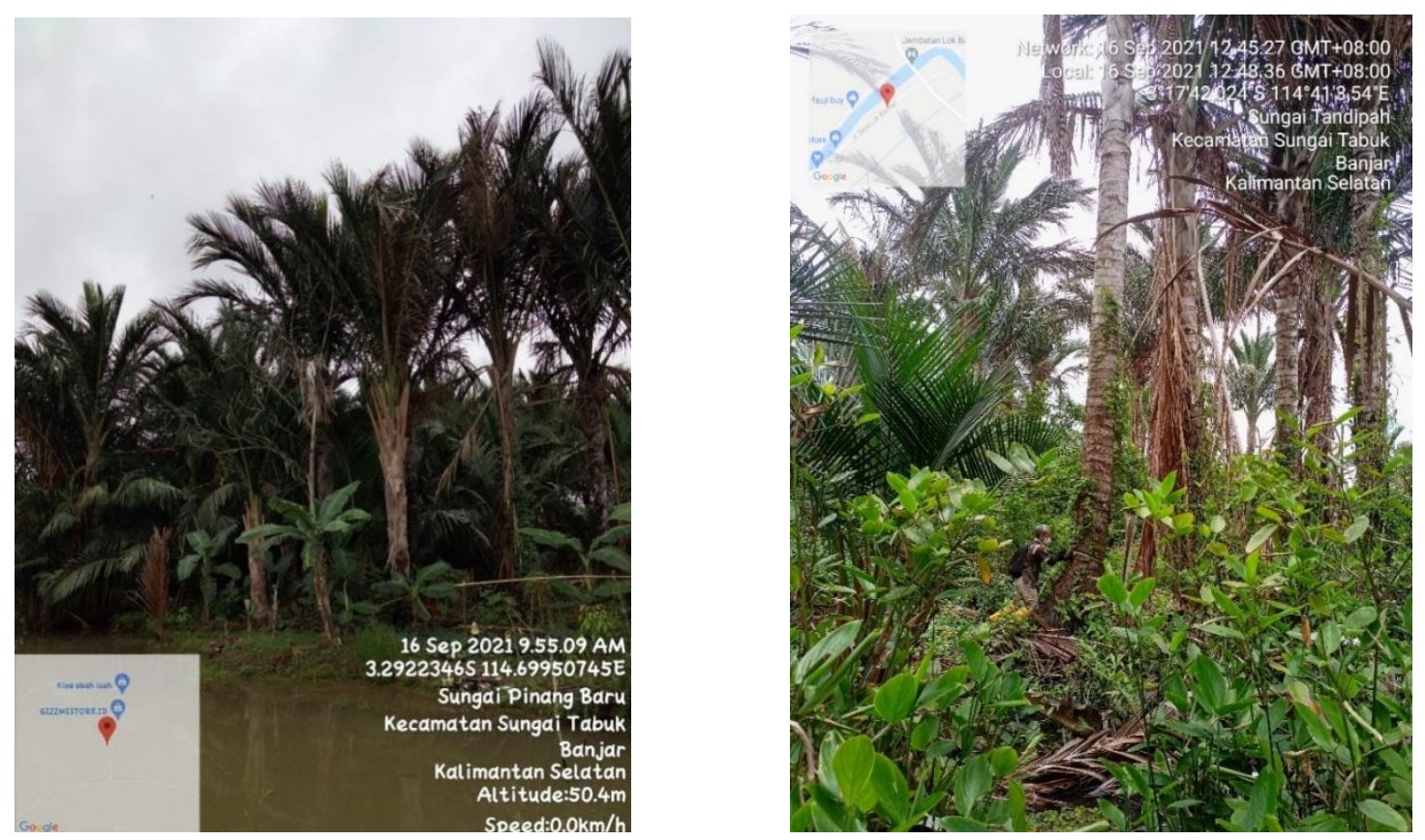

Figure 2 - Description of M.sagu in the field

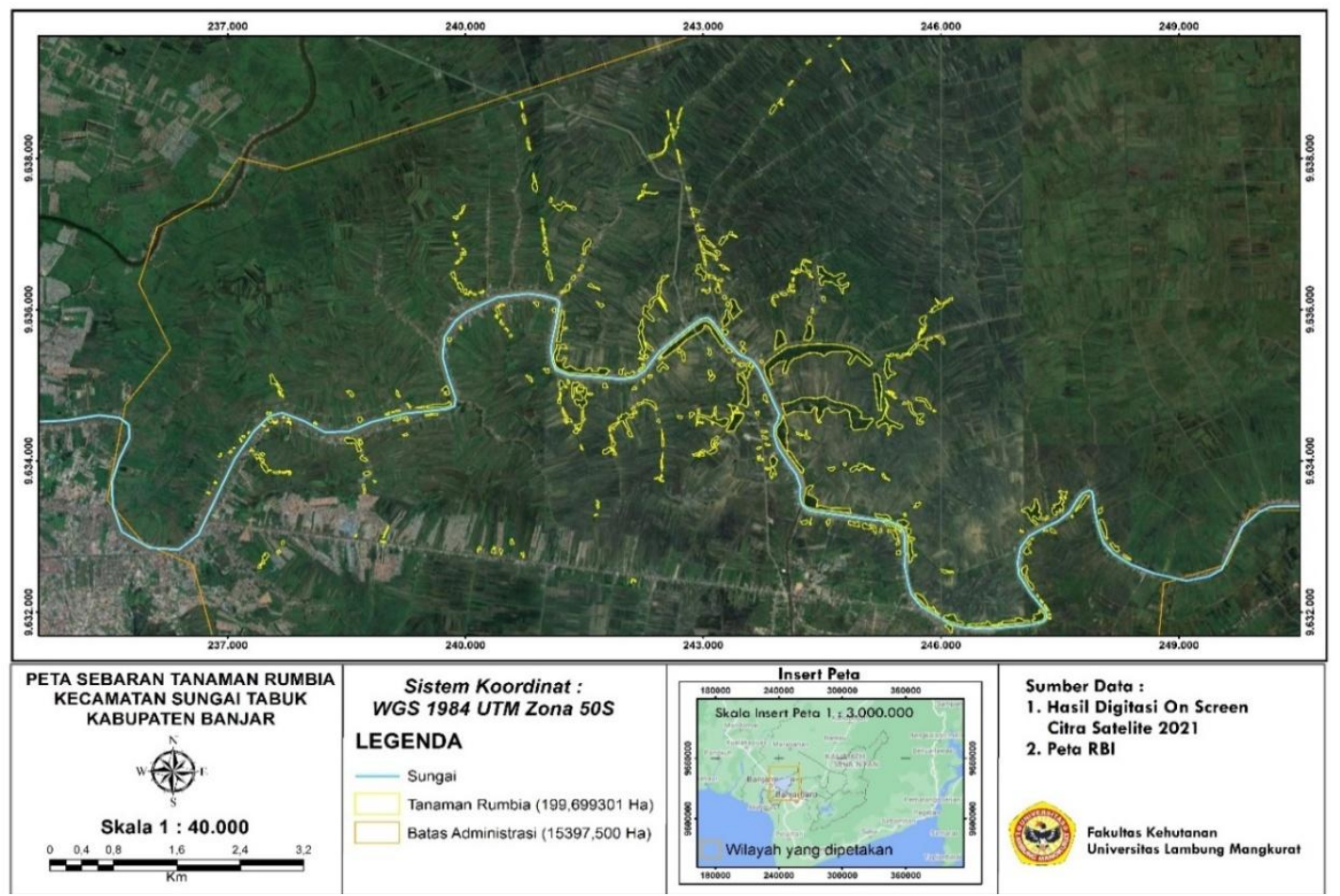

Figure 3 - Spatial distribution of $\underline{M}$.sagu forest in Sungai Tabuk subdistrict

The potential of M.sagu forest. There were 12 square plots measuring $20 \mathrm{~m} \times 20 \mathrm{~m}$ made to measure vegetation data. The potential of sago forest is analyzed by calculating the diameter, height and volume of trees. The average height and diameter of the plant was calculated by using the following formula:

$$
\bar{d}=\sum_{i=1}^{n} d_{i} / n_{\bar{t}}=\sum_{i=1}^{n} t_{i} / n
$$

Where: $d=$ diameter $(\mathrm{cm}) ; \mathrm{t}=$ height $(\mathrm{m}) ; \mathrm{di} / \mathrm{t} \mathrm{i}=$ diameter and height of tree to- $\mathrm{I} ; \mathrm{n}=$ number of trees sample. 


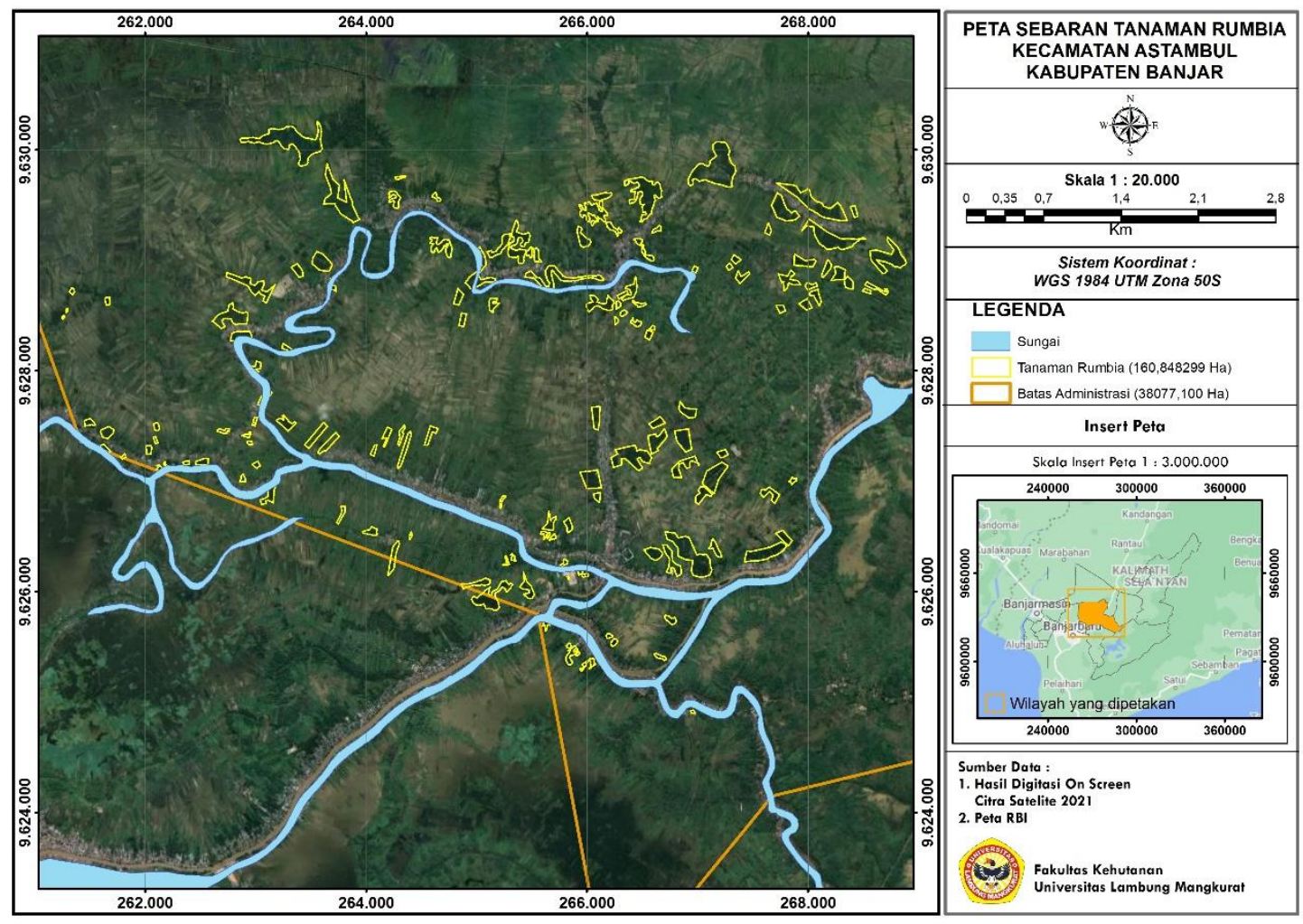

Figure 4 - Spatial distribution of M.sagu forest in Astambul subdistrict

The volume of the M.sagu trees was calculated by the following formula approach:

$$
V=1 / 4 \cdot \pi \cdot d 2 \cdot h \cdot f
$$

Where: $V=$ Volume of tree; $\pi=3,14 ; d=$ Diameter breast height $(1,3 \mathrm{~m}) ; \mathrm{h}=$ Tree height; $f=$ Correction factor $(0,7)$.

The result of analysis average potential of M.sagu forest/ha then converted to the total area covered by M.sagu forest. The calculation results are presented in a tabulation matrix.

\section{RESULTS AND DISCUSSION}

The distribution of M.sagu forest is administratively spread over 7 sub-districts. The distribution of M.sagu forest based on administrative area in Banjar District is listed in Table 1.

Table 1 - Distribution of M.sagu in Banjar district South Kalimantan

\begin{tabular}{llll}
\hline $\mathrm{Nu}$ & Location & Administrative area (ha) & M.sagu forest area [ha] \\
\hline 1 & AluhAluh sub district & 8284 & 0.82 \\
2 & Gambut sub district & 12930 & 1.76 \\
3 & Sungai Tabuk sub district & 14730 & 199.70 \\
4 & Martapura sub district & 22140 & 34.88 \\
5 & Karangintan sub district & 21535 & 3.32 \\
6 & Astambul sub district & 21650 & 160.85 \\
7 & SimpangEmpat sub district & 14180 & 0.30 \\
\hline & TOTAL & 115449 & 401.62 \\
\hline
\end{tabular}

There are 2 subdistricts that have the largest M.sagu forest area, namely Sungai Tabuk sub district and Astambul sub district. Based on the comparison with the area of Banjar district, the percentage of M.sagu forest area is $0.09 \%$ of the total area of Banjar district $(466,850 \mathrm{ha})$. This percentage is quite small. M.sagu forest habitat is mostly on rivarian land. 
Hariyanto (2011) stated that M. sago habitats are generally located in swampy areas and around rivers (rivarian).

The accuracy of interpretation in classifying M.sagu forest can be seen in Table 2.

Table 2 - Percentage of interpretation accuracy

\begin{tabular}{lll}
\hline $\mathrm{n} / \mathrm{n}$ & M.sagu Forest & Non M.sagu Forest \\
\hline Interpretation & 25 plot & $25 \mathrm{plot}$ \\
Observed & 24 plot & $25 \mathrm{plot}$ \\
Percentage of accuracy & $96 \%$ & $100 \%$ \\
Mean of accuracy & - & $98.0 \%$ \\
\hline
\end{tabular}

The accuracy of interpretation reaches $98 \%$. Several factors that cause the high accuracy of interpretation are: the color (tone) of M.sagu is very clearly identified in the composite image. The color of M.sagu looks dark green, the shape of M.sagu is also relatively clear with a crown shape that can be distinguished from other palm trees such as Cocos nucifera and Elaisguinensis. The pattern of M.sagu forest is generally clustered with coarse texture as a result of the formed canopy stratification. The indicator of association of M.sagu with rivers is also a guide in accurate interpretation. Inaccuracy of interpretation related to changes in land use from M.sagu forest to residential areas. The form of land use change in sago forest generally turns into residential areas or rice fields.

The spatial distribution pattern of M.sagu forest in the 2 subdistrict areas with the largest area is shown in Figure 2 and Figure 3.

M.sagu found in the research location grows on the borders of large rivers and some small rivers. The characteristics of the place where M.sagu grows in South Kalimantan are on alluvial soil andassociated with rivers or creeks. Hermawan (2010) stated that one type of soil where M.sagu grows is alluvial soil. Some M.sagu patches grow in basins that are flooded with water. The M.sagu forest patches in these inundated areas are usually adjacent to rice fields and irrigation canals.

The two sub-districts that have a large number of M.sagu are geographically located side by side and are located along a large river (Sungai Martapura). The Martapura River is included in the sub watersheet of the Barito Watersheet. The Barito River is the largest and longest watersheet in South Kalimantan Province.

The potential of M.sagu forest. The calculation of the potential of M.sagu forest is limited to trees $>20 \mathrm{~cm}$ in diameter. The results of the analysis of the potential of M.sagu forest in Banjar district are listed in Table 3.

Table 3 - The potential of M.sagu forest in Banjar district South Kalimantan

\begin{tabular}{lll}
\hline No & The Potential Vegetation of M.sagu Forest & Value \\
\hline 1 & Range of diameter & $21.2-58.2 \mathrm{~cm}$ \\
2 & Mean of diameter & $39.18 \mathrm{~cm}$ \\
3 & Range of height & $5-25 \mathrm{~m}$ \\
4 & Mean of height & $14.18 \mathrm{~m}$ \\
5 & Number of trees/ha (diameter $20 \mathrm{~cm})$ & $119 \mathrm{trees}$ \\
6 & Total volume/ha & $3.42 \mathrm{m3}$ \\
7 & Coverage area of M.sagu forest & $401.62 \mathrm{ha}$ \\
\hline Total volume of M.sagu in Banjar district & $1372.87 \mathrm{m3}$ \\
\hline
\end{tabular}

The potential of M.sagu forest is quite large. The potential for M.sagu forest with a diameter $>20 \mathrm{~cm}$ is 119 trees/ha. M.sagu that is cut down for starch production has a diameter of $>50 \mathrm{~cm}$ (mature tree). The number of individual mature trees of M.sagu in Banjar district reaches 48 stems/ha. According to information from several home industries of M.sagu starch in Banjar district, one mature tree of M.sagu can produce $200 \mathrm{~kg}$ of wet M.sagu starch. Thus, the total production of wet starch from M.sagu forest in Banjar district is 3,855 tons. This result is greater than the prediction of M.sagu production in 2021 throughout South Kalimantan with a production volume of 3,724 tons (Indonesian Ministry of Agriculture. 2020). These results illustrate that M.sagu production in South Kalimantan can be further 
increased, because the distribution areas of M.sagu in other districts such as Tapin, Hulu Sungai Tengah, Hulu Sungai Utara, Hulu Sungai Selatan and Barito Kuala, have not been taken into account.

\section{CONCLUSION}

The spatial distribution of M.sagu forest is spread over 7 sub-districts. The area covered by M.sagu forest in Banjar Regency is 401.62 ha. There are 2 subdistricts that have the largest M.sagu forest area in Banjar district, namely Sungai Tabuk sub district and Astambul sub district. M.sagu found in the research location grows on the borders of large rivers and some small rivers. The percentage of M.sagu forest area is $0.09 \%$ of the total area of Banjar district (466,850 ha). The potential of M.sagu forest with a diameter $>20 \mathrm{~cm}$ is 119 trees/ha. M.sagu tree that is cutting down for starch production has a diameter $>50 \mathrm{~cm}$ (mature tree). The number of individual mature trees of M.sagu in Banjar district reaches 48 stems/ha. The total potential production of wet starch from M.sagu forest in Banjar district is 3,855 tons. The results of this research indicated that the production of M.sagu forests can be increased to improve the welfare of the community.

\section{ACKNOWLEDGEMENTS}

The authors would like to thank the Institute for Research and Community Service (Lembaga Penelitian dan PengabdianKepada Masyarakat) University of Lambung Mangkurat, Banjarmasin, South Kalimantan Indonesia, which has supported this research fund.

\section{REFERENCES}

1. Acreman M.C., J.O. Mounford. 2010. Wetland Management. In R.C. Ferrier and A. Jenkins. Handbook of Catchment Management. A John Wiley \& Sons, Ltd. P 19-49.

2. Alfonfs, J.B dan Rivaie, A.A. 2011. M.sagu Supports to Food Security in Facing the Impact of Climate Change, PerspektifVol. 10 No.2 /Des 2011. Hlm 81 - 91 ISSN: 14128004.

3. Bintoro, M.H., N. Mashud, dan Novanianto, H. 2007. Status teknologi of M.sagu. Paper in Lokakarya Pengembangan Sagu di Indonesia. Batam.

4. Bintoro. 2008. M.sagu Farming. 71 hal. Bogor: IPB Press.

5. Bintoro, M.H., M.Y.J. Purwanto, S. Amarillis. 2010. M.sagu in peatland. IPB press. Bogor. 169 hal.

6. Buyken, A. E., Y, Kerllerhoff, S. Hahn, A. Kroke, dan T, Remer. 2006. Urinary C-peptide Excretion in Freellving Healthy Childrenis Related to Dietary Carbohydrate Intake But Not to The Dietary Glycemic Index, J Nutr136(7);1628-183.

7. Food Agriculture Organization (FAO). 2008. Scooping Agriculture - Wetland Interaction Towards A Sustainable - Multiple Response Strategy. FAO. Rome.

8. Flach, M. 1983. M.sagu Palm Domestication, Explantation, and Production FAG Plant Production and Protection Paper. $85 \mathrm{p}$.

9. Hariyanto, B. 2011. Benefits of Sago Plants (Metroxylon sp.) in Food Supply and Environmental Quality Control. Journal of Environmental Engineering (Jurnal Teknik Lingkungan). 12 (2): $143-152$.

10. Hamlan Ihsan, Nadra Khairiah, Rufida. 2018. Characteristics of Physical and Chemical Properties Edible Film of Sago Rumbia Starch (Metroxylon sagu Rottb) for Capsule Shell Raw Materials. Journal of RisetIndustri Hasil Hutan Vol.10, No.2, Desember 2018: 55-62.

11. Hermawan, E. 2010. Biofuel Investment Profile from Sagu. Dirjen Pengolahan dan Pemasaran Hasil Pertanian. www.pphp.deptan.go.id.

12. Indonesia Ministry of Agricultur. 2017. Production Area by Province in Indonesia, 2017 2021. Directorate General of Estate. https://www.pertanian.go.id/home/index.php?show= repo\&fileNum=220. 
13. Louhenapessy, J.E. 2006. Potential and Processing of M.sagu in Maluku Paper in Lokakarya Sagu. Dalam Revitalisasi Pertanian Maluku. Ambon 29-31 Mei 2006 (in Indonesia).

14. Nurlestari, Y. 2000. Strategic Planning for Integrated M.sagu Agribusiness Development on Siberut Island. Thesis Program Pascasarjana Manajemen dan Bisnis IPB Universitu. Bogor.

15. Indonesia Government. 2020. Peraturan Presiden Nomor 18 tahun 2020 tentang RPJMN 2020-2024. Jakarta Indonesia.

16. Suryana, A. 2007. Direction and Strategies for the Development of M.sagu in Indonesia. Paper in Lokakarya Pengembangan Sagu Indonesia. Batam, 25-26 Juli 2007.

17. Syakir, M., Elna, M. 2013. Potential of M.sagu Plants (Metroxylon spp.) As Bioenergy Raw Materials.JurnalPerspektif. Vol.12, No.2:57-64.

18. Tarigan DD. 2001. Sago Strengthens Source of Food Self-Sufficiency. Warta Litbang Pertanian Prosiding Saguuntuk Ketahanan Pangan. Manado: Balitka Manado; 2001. p. 23(5):1-3.

19. Tumbel N. 2014.Performance Test of Processing Equipment of Sago Baruk (Arenga Microcarpa). Jurnal Penelitian Teknologi Industri Vol. 6 No. 1 Juni 2014: 43-54.

20. Wahyuningtyas R.S. Junaidah dan Susi Andriani 2018. Sago Processing in Pemakuan Village, Banjar Regency, South Kalimantan Province. Prosiding Seminar Nasional Teknologi dan Inovasilndustri, Banjarbaru 19 Juli 2019. pp. 83-90. Baristand. 